\title{
STRAINED APPLICATION OF THE VIABILITY STANDARD TO IN VITRO FROZEN EMBRYOS - DECONSTRUCTING JETER V. Mayo Clinic Arizona
}

\author{
Brock J. Heathcotte, Esq.*
}

\section{TABLE OF CONTENTS}

I. INTRODUCTION

II. How THE ISSUE OF WHEN A HUMAN LIFE BEgINS ARISES IN

COURT 253

III. A BRIEF HISTORY OF RELEVANT ARIZONA LAW ..............................255

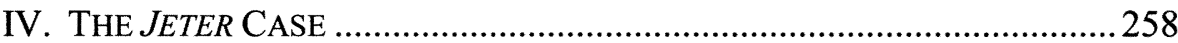

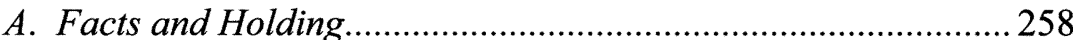

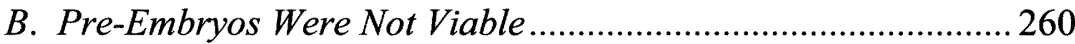

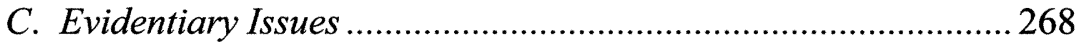

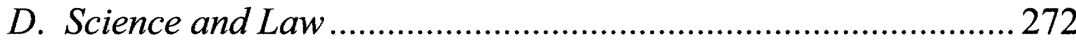

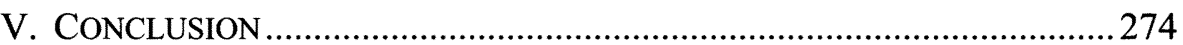

\section{Introduction}

American courts typically examine the best available scientific evidence relevant to a controversy before arriving at a decision. This evidence normally comes not only in the form of expert testimony in trials but also as extrajudicial scientific treatises utilized by courts of appeal. ${ }^{1}$ Most courts, however, remain unwilling to utilize the best available evidence in developmental biology when deciding cases that require a decision about when a human life begins. While judicial opinions often describe some aspects of embryonic biology and fetal life, courts usually fall back on legal precedent such as the viability standard popularized by abortion law instead of using the most relevant scientific evidence to arrive at a decision about when a life begins.

Many complex legal circumstances arose in the past which seemed to require for their resolution a definition of when human life began. The current

* Ph.D Candidate, 2007, Arizona State University, Tempe, Arizona; J.D., 1990, Arizona State University, Tempe, Arizona; B.A., 1987, University of Arizona, Tuscon, Arizona. The author wishes to gratefully acknowledge the editorial comments of Manfred Laubichler, Ph.D., J. Alan Rawls, Ph.D., Jason S. Robert, Ph.D., and the professional editing of Barbara A. Grant.

1. See Kenneth Culp Davis, An Approach to Problems of Evidence in the Administrative Process, 55 HARV. L. REV. 364, 402 (1942) (providing a widely regarded, scholarly legal discussion of sources of evidence). 
and future science of reproductive technologies such as stem cell and human embryo research, in vitro fertilization, and the potential for artificial wombs, calls into question the judiciary's continuing reliance on standards from a prior technological age that were devised for socially pragmatic reasons at the time. It will soon be necessary for courts to re-examine when a human life begins in order to clearly articulate a sustainable legal strategy for dealing with the earliest stages of human biological development that has been more clearly illuminated by scientific advances. While each judge is entitled to consider the implications of scientific practices in the context of each specific case before the court, a new era now exists where the decision provided should include a concerted effort to balance legal precedence with the evidence provided by new reproductive technologies. This idea is shared by Supreme Court Justice Stephen Breyer, albeit in a more general context:

I believe there is an increasingly important need for law to reflect sound science, and I remain optimistic about the likelihood that it will do so. It is common to find cooperation between governmental institutions and the scientific community where the need for that cooperation is apparent. Today, as a matter of course, the President works with a science adviser, Congress solicits advice.. . from the National Academy of Sciences, and the scientific regulatory agencies will often work with outside scientists, as well as their own, in their efforts to develop a work product that reflects good science. ${ }^{2}$

For decades courts have avoided deciding when life begins. But, if we take Justice Breyer's comments seriously, the time has come for the legal system to take a more complete and informed decision about defining human life based on the best available science.

Recently, in the case of Jeter v. Mayo Clinic Arizona, one court undertook this challenge to define human life based on some aspects of developmental biology, but failed to use this analysis for any legal purpose. ${ }^{3}$ While the Jeter court managed to avoid controversy without applying the relevant science, it failed to address the issue of great importance posed by the case-were cryogenically preserved human embryos living human beings whose lives are protected by law? The Jeter court's reluctance to answer the fundamental legal

2. Stephen G. Breyer, The Interdependence of Science and Law, 82 JUDICATURE 24, 26 (1998-1999).

3. Jeter v. Mayo Clinic Arizona, 121 P.3d 1256, 1256 (Ariz. Ct. App. 2005). The case is still pending trial in superior court. However, the question of importance to this paper, whether a wrongful death claim for loss of frozen embryos was allowed under Arizona law, has been resolved in the negative. 
question posed by advancing technological proficiency in manipulation of human embryos was justified by passing the question to the Arizona Legislature.

Legislatures have not been as reluctant to take a position on when life begins and have in many instances enacted laws protecting human life from conception. ${ }^{4}$ Further complicating this discussion, at least one court appeared willing to allow a jury to decide when life begins before being reversed on appeal. ${ }^{5}$ This development will likely make the application of legal rules in this area less coherent and will create further ambiguity in defining when life begins.

\section{How The IsSUe OF WHEN A HuMAN LIFE BEgINS ARISEs IN COURT}

Appeals were filed with the Illinois ${ }^{6}$ and South Dakota ${ }^{7}$ courts that will further define the parameters of legal protection for human embryos. Each case followed a different path to arrive at the same question - when does a human life begin? The cases were brought as a claim for wrongful death in Illinois, and as a request for an injunction to prevent enforcement of an abortion law in South Dakota. The question of when life begins has also arisen in cases brought as medical malpractice, civil accident/injury torts, and as criminal prosecution. ${ }^{8}$

These various forms of cases arise under common law, statutory causes of action, and beg additional constitutional questions. Various state courts and legislatures have arrived at different standards for recognizing when a human life begins in each of these legal contexts. ${ }^{9}$ Even within individual states, the

4. Unborn Victims of Violence Act, 18 U.S.C. $\S 1841$ (d).

5. See Acuna v. Turkish, 894 A.2d 1208 (N.J. Super. Ct. App. Div. 2006), rev'd, 930 A.2d 416 (N.J. 2007). The New Jersey Court of Appeals ruled that a jury should decide whether an abortion physician must tell his patient that her six to seven week old embryo was a distinct living individual. Acuna sued Turkish for lack of informed consent and severe emotional distress upon discovering after the abortion that her unborn child was more biologically developed than she was led to believe. However, the Court of Appeals was reversed by the New Jersey Supreme Court.

6. See Miller v. Am. Infertility Group, No. 02-L-7394 (Circ. Ct. Cook County, Ill., Feb. 4,2005 ) (ruling that a cryopreserved human embryo lost by the fertility clinic was the proper subject of a wrongful death lawsuit because the frozen embryo fit within the Legislature's definition of human being. The case is on appeal to the Illinois Court of Appeals).

7. See Planned Parenthood v. Rounds, 467 F.3d 716 (8th Cir. 2006) (ruling that an injunction was appropriate against enforcement of a South Dakota law that required abortion providers to tell patients, among other things, that "the abortion will terminate the life of a whole, separate, unique, living human being," in order to satisfy informed consent laws). After South Dakota voters rejected an abortion law in a November 2006 referendum, the decision was vacated and a rehearing en banc was granted.

8. Bonbrest v. Kotz, 65 F.Supp. 138 (D.D.C. 1946) (medical malpractice); Dietrich v. Inhabitants of Northampton, 138 Mass. 14 (1884) (slip and fall); People v. Davis, 872 P2d. 591 (Cal. 1994) (feticide).

9. For different state treatments of the status of embryos and fetuses, see Alan S. Wasserstrom, Annotation, Homicide Based on Killing of Unborn Child, 64 A.L.R. 5th 671 (1998); Annotation, Liability for Child's Personal Injuries or Death Resulting From Tort Committed 
standard definitions applied by courts under common law, legislatures by statute, and the federal courts by constitutional law are often varied. For example, the legal definition may be phrased in terms of the "personhood" of the embryo or fetus, or whether the embryo or fetus is a "human being," but in other instances may be defined in terms of "potential" persons or human beings. Many states tend to use the term "unborn child" as a generic term for the embryo and fetus in the womb. ${ }^{10}$ Many other scientific and unscientific terms have also been used which further diminish the specificity with which a unified legal definition can be constructed. Given the various standards that exist for defining life from the point of conception through to birth and with the complex legal standards established by single institutions within a single state who have articulated several different standards over the past fifty years, ${ }^{11}$ the result is a legal maze through which abortion providers, fertility clinics, and human embryo researchers must navigate with legal uncertainty. ${ }^{12}$

This Article will examine the confounding issue of defining life by primarily examining the language codified in Arizona legislation and by reviewing recent case law, particularly the case of Jeter v. Mayo Clinic Arizona. ${ }^{13}$ The primary focus will be to analyze two issues; who should decide the ultimate question of defining life and how to determine the level and type of evidence required to facilitate the decision. Two quotes illustrate the starting point from which to begin this discussion. First, a statement from the Jeter opinion where Judge Donn Kessler opined "[C]urrent scientific knowledge concerning embryonic development underscores the difference between a viable fetus in vivo and an eight-cell, three-day-old pre-embryo in vitro. Such knowledge is important to help guide, but not dictate resolutions of the problem."14 Second, a quote from a book written by Dr. Jane Maienschein of the Arizona State University School of Life Sciences, who was often cited in the Jeter opinion,

Against Child's Mother Before Child Was Conceived, 91 A.L.R.3d 316 (1979); Sheldon R. Shapiro, Annotation, Right to Maintain Action or to Recover Damages for Death of Unborn Child, 84 A.L.R. 3d 411 (1978); Roland F. Chase, Annotation, Liability for Prenatal Injuries, 40 A.L.R. 3d 1222 (1971).

10. See ARIZ. Rev. Stat. ANN. § 13-1102-1105 (Arizona homicide statutes).

11. The evolving judicial interpretation of the word "person" in the Illinois wrongful death statute is a prime example. See Amber N. Dina, Wrongful Death and the Legal Status of the Previable Embryo: Why Illinois is on the Cutting Edge of Determining a Definitive Standard for Embryonic Legal Rights, 19 REGENT U. L. REV. 251, 251 (2006-2007); Miller v. American Infertility Group, No. 02-L-7394 (Circ. Ct. Cook County, Ill., Feb. 4, 2005); Smith v. Mercy Hospital, 560 N.E.2d 1164 (Ill. App. Ct. 1990); Green v. Smith, 377 N.E.2d 37 (Ill. 1978); Chrisafogeorgis v. Brandenberg, 304 N.E.2d 88 (Ill. 1973); Amann v. Faidy, 114 N.E.2d 412 (Ill. 1953); Allaire v. St. Luke's Hospital, 56 N.E. 638 (Ill. 1900).

12. Federal and state regulation and funding rules for embryo research are more immediately pertinent to researchers, but this paper focuses on the ultimate question that is answered by law rather than regulation. It does a research facility no good to have funding lined up for human embryo research, and all the mechanisms in place to perform the research, if the state it is located in is prepared to prosecute for manslaughter when the research actually begins, or if the embryo progenitors are allowed to sue the facility for wrongful death of the embryos.

13. Jeter v. Mayo Clinic Arizona, 121 P.3d 1256 (Ariz. Ct. App. 2005).

14. Jeter, 121 P.3d at 1265 (citing MAIENSCHEIN, infra note 18, at 10). 
"[E]ach stage of a developing individual is alive, but we might well decide that the earliest stages do not yet meaningfully count as a life." 15

These statements give rise to additional questions this paper will attempt to address. Is the science cited by courts and legislatures "good" science? Whom does science guide and through what mechanisms? Who is the "we" that must decide what counts as a life? And finally, is the existence or nonexistence of a human life a question of fact or law?

\section{A BRIEF HISTORY OF RELEVANT ARIZONA LAW}

Arizona currently has a confused but typical statutory scheme for protection of the human embryo and fetus. ${ }^{16}$ Adding to this complexity, Arizona courts changed their interpretations of those statutes in recent years. ${ }^{17}$ Furthermore, in Arizona, there is a constitutional provision preserving the right to civil actions. ${ }^{18}$ So, for example, if an unborn child is injured while in the womb, the unborn child is afforded the right to sue for compensation at any time after birth but prior to reaching the age of majority plus the applicable statute of limitations- which normally means up to the age of twenty. ${ }^{19}$ If the unborn child dies before birth, survivors may bring an action for the unborn child's wrongful death but only if the injury occurred after the unborn child reached viability. ${ }^{20}$ However, someone who causes the death of an unborn child at any stage of development is susceptible to prosecution and punishment under criminal statute with the exception being abortion which is legal under federal constitutional law.

Under the current Arizona statutory scheme, the crime of manslaughter is a class two felony when an individual causes the death of an "unborn child" at

15. Jane Maienschein, Whose View of Life? Embryos, Cloning, and Stem Cells (Harvard University Press) (2003) [hereinafter MAIENSCHEIN] (Dr. Maienschein is on this author's Ph.D. dissertation committee.).

16. See, ARIz. REV. STAT. ANN. § 13-105(26), § 13-1101(3), § 13-1102-1105, § 13-604, § 13-604.1, § 13-702-703.1, § 12-502, § 12-542 (2007); see also Ariz. Const. art. XVIII, § 6; ArIz. ReV. StAT. ANN. § 12-611 (2007); State v. Hampton, 140 P.3d 950 (Ariz. 2006); State v. Cotton, 5 P.3d 918 (Ariz. Ct. App. 2000); Vo v. Super. Ct. in \& for County of Maricopa, 836 P.2d 408 (Ariz. Ct. App. 1992); State v. Amaya-Ruiz 800 P.2d 1260 (Ariz. 1990); Larriva v. Widmer, 415 P.2d 424 (Ariz. 1966); Kilmer v. Hicks, 529 P.2d 706 (Ariz. Ct. App. 1974); Summerfield v. Super. Ct., 698 P.2d 712 (Ariz. 1985); Burnham v. Miller, 972 P.2d 645 (Ariz. Ct. App. 1998); Jeter v. Mayo Clinic Arizona, 121 P.3d 1256 (Ariz. Ct. App. 2005).

17. See the changing interpretation of the word "person" in ARIz. REV. STAT. ANN. § 12611 (2007) by Arizona courts in Kilmer v. Hicks, 529 P.2d 706 (Ariz. Ct. App. 1974); Summerfield v. Super. Ct., 698 P.2d 712 (Ariz. 1985); Jeter v. Mayo Clinic Arizona, 121 P.3d 1256 (Ariz. Ct. App. 2005).

18. Ariz. Const. art. XVIII, $\S 6$ ("The right of action to recover damages for injuries shall never be abrogated, and the amount recovered shall not be subject to any statutory limitation.").

19. No case has tested whether an unborn child can stand as a party plaintiff in an action. It is questionable whether such a case could come to decision because human gestation is faster than human litigation. On the other hand, a lawsuit filed on behalf of a cryogenically preserved embryo could get its day in court.

20. Summerfield v. Super. Ct., 698 P.2d 712 (Ariz. 1985). 
any stage of biological development which can range anywhere from the point of implantation to emergency birth precipitated as a result of an injury to the fetus's mother. ${ }^{21}$ However, the wrongful death civil statute ${ }^{22}$ speaks only of death of a "person," which has been interpreted by the Arizona Supreme Court to include a stillborn fetus that is "viable." (Of note, the court in this decision did not address earlier stages of development. ${ }^{23}$ Therefore, under Arizona law, for the first five or six months of a pregnancy the state can prosecute a wrongdoer for violating the manslaughter statute in causing the death of an embryo or fetus, but the parents cannot sue the wrongdoer under the wrongful death statute for the same act.

The manslaughter statute has been amended twice in recent times. In 1983 , the addition of statutory language made it a crime to cause the death of an unborn child. ${ }^{24}$ In 2005 , the Legislature again amended the statute by adding additional language to clarify that a crime occurs only if the unborn child was "in the womb" at the time of the wrongful act. ${ }^{25}$ This condition may have been

21. ARIZ. REv. StAT. ANN. § 13-1103 (2007):

A. A person commits manslaughter by:

1. Recklessly causing the death of another person; or...

5. Knowingly or recklessly causing the death of an unborn child by any physical injury to the mother.

B. An offense under subsection A, paragraph 5 of this section applies to an unborn child in the womb at any stage of its development. A person shall not be prosecuted under subsection A, paragraph 5 of this section if any of the following applies:

1. The person was performing an abortion for which the consent of the pregnant woman, or a person authorized by law to act on the pregnant woman's behalf, has been obtained or for which the consent was implied or authorized by law.

2. The person was performing medical treatment on the pregnant woman or the pregnant woman's unborn child.

3. The person was the unborn child's mother.

C. Manslaughter is a class 2 felony.

22. ARIZ. REV. STAT. ANN. § 12-611 (2005):

When death of a person is caused by wrongful act, neglect or default, and the act, neglect or default is such as would, if death had not ensued, have entitled the party injured to maintain an action to recover damages in respect thereof, then, and in every such case, the person who or the corporation which would have been liable if death had not ensued shall be liable to an action for damages, notwithstanding the death of the person injured, and although the death was caused under such circumstances as amount in law to murder in the first or second degree or manslaughter.

23. Summerfield v. Super. Ct., 698 P.2d 712 (Ariz. 1985).

24. See Ariz. Rev. StaT. ANN. § 13-1103 (2007). From the 1983 amendment until the 2005 amendment, section A(5) read, "Knowingly or recklessly causing the death of an unborn child at any stage of its development by any physical injury to the mother of such child which would be murder if the death of the mother had occurred."

25. ARIZ. Rev. Stat. ANN. § 13-1103 (2007). 
unclear from the wording of the statute prior to the 2005 amendment, particularly for those interested in performing in vitro human embryo research.

The legislature has not amended the wrongful death statute since 1939 and it remains essentially the same since territorial days. ${ }^{26}$ The courts, however, have changed their interpretation of the statute. In 1974, the Arizona Supreme Court ruled in the case of Kilmer $v$. Hicks that a nine-month-old fetus who was overdue by two days was not a "person," as the term was used in the Arizona wrongful death statute in relation to a pregnant woman who died along carrying a fetus in an automobile accident. ${ }^{27}$ The court noted that the majority standard among states was that one must be born in order to be legally recognized as a "person" under the statute. ${ }^{28}$ In addition, in making their decision the court was guided by the abortion case of Roe v. Wade which was decided the previous year. ${ }^{29}$ The Arizona Supreme Court stated, "[w]e believe that the meaning of the word 'person' in the statute is clear and unambiguous in its noninclusion of a viable fetus. It is a matter for the legislature to expand the statutory definition if it deems it appropriate and not a matter for this court."30

However, in 1985, the same Arizona court reversed itself by finding that a "viable" fetus was a "person" within the meaning of the Arizona wrongful death statute in the Summerfield case. ${ }^{31}$ Summerfield was decided only two years after the legislature changed the criminal law to punish for the crime of feticide as described above. In the decision, the court noted that the criminal statute was included in the section associated with the killing of "persons.", 32 In the eleven years between Kilmer and Summerfield, the majority of states changed their interpretation of "person" for wrongful death purposes to include a viable fetus, and Arizona subsequently followed suit. ${ }^{33}$

26. ARIZ. Rev. Stat. ANN. § 12-611 (2007).

27. Kilmer v. Hicks, 529 P.2d 706 (Ariz. Ct. App. 1974).

28. Id.

29. Roe v. Wade, 410 U.S. 113, 158 (1973) (a fetus is not a person within the meaning of the 14th Amendment).

30. Kilmer, 529 P.2d at 708.

31. Summerfield v. Super. Ct., 698 P.2d 712 (Ariz. 1985). Baby Girl Summerfield was stillborn allegedly because of medical malpractice by defendants James Colleen, M.D., and Richard Lott, M.D. The trial court dismissed the claim for wrongful death and the Summerfields filed a special action seeking reversal of the judge's decision.

32. The statute, ARIZ. REV. STAT. ANN. § 13-1103 (2007), expanded criminal protections to any stage of development, but the Summerfield court was only presented with a case of a viable fetus. It is regular practice for courts to resolve only the issue currently before them. The fetus in the Summerfield case was viable. Whether or not the Summerfield court would have gone further to allow a wrongful death action to a non-viable fetus had they been faced with such a case is unknowable.

33. Many states have identical wrongful death statutes that do not define "person." In all of those states, the courts have been forced to come up with a definition. Most states have drawn a line at viability, but a growing number of states have expanded personhood in the wrongful death context even to the non-viable fetus or embryo, sometimes on the basis of legislative intent expressed in criminal statutes. See, Ronald F. Chase, Annotation, Liability for Prenatal Injuries, 40 A.L.R. 3d 1222 (1971); Michael P. Penick, Annotation, Wrongful Death of Fetus, 19 Am. Jur. Proof of Facts 3d 107 (2007); Sheldon R. Shapiro, Annotation, Right to 
The majority rule, which now recognizes that a death action will lie under the circumstances present here, acknowledges that the common law has evolved to the point that the word "person" does usually include a fetus capable of extrauterine life. The majority also recognizes that the common law now holds that if the fetus survives it may recover for injuries sustained in the womb. The common law now also permits a death action if the infant survives birth and then dies from injuries sustained in the womb. The majority finds no logic in the premise that if the viable infant dies immediately before birth it is not a "person" but that if it dies immediately after birth it is a "person."

We take note, further, that the magic moment of "birth" is no longer determined by nature. The advances of science have given the doctor, armed with drugs and scalpel, the power to determine just when "birth" shall occur. We believe that the common law now recognizes that it is the ability of the fetus to sustain life independently of the mother's body that should determine when tort law should recognize it as a "person" whose loss is compensable to the survivors. We acknowledge, of course, that this, too, is an artificial line, difficult at times to determine. It is not possible to draw any line without being arbitrary to some extent. Nevertheless, we believe that with regard to the issue of recognizing a loss to the survivors, viability is a less arbitrary and more logical point than the moment of birth. The moment of viability may be difficult to prove in those few cases where that moment and the tortious injury are temporally close. We do not believe, however, that a just remedy should be denied in all cases simply because proof may be difficult in a few. ${ }^{34}$

\section{THE JETER CASE}

\section{A. Facts and Holding}

Belinda and William Jeter went to the Mayo Clinic Arizona to obtain information to help them conceive a child. After consultation, the couple decided 
to attempt in vitro fertilization. Shortly thereafter, Dr. Anita Singh retrieved eggs from Mrs. Jeter at the Mayo Clinic after which the eggs were fertilized with Mr. Jeter's sperm. The resulting zygotes grew and developed for two to three days until they became identifiable as eight-cell organisms which the court referred to as pre-embryos. Two attempts to impregnate Mrs. Jeter failed, and the remaining pre-embryos were frozen. Unwilling to give up, the Jeters decided to try in vitro fertilization again, but with a different clinic, the Arizona Center for Fertility Studies to which the Jeters arranged for transfer of the remaining pre-embryos. ${ }^{35}$

According to the Jeters, ten pre-embryos should have been transferred by the Mayo Clinic, but two of the four cryotubes used for transportation were empty, and only five pre-embryos arrived at the Arizona Center. ${ }^{36}$ Mrs. Jeter underwent a tubal embryo transfer at the Arizona Center, became pregnant, and delivered a daughter. Still, the Jeters wanted to have more children with the help of the Arizona Center for Fertility Studies, but no pre-embryos remained. With the loss of the pre-embryos, the Jeters were concerned about the additional discomfort and cost that would be required to replace them. The Jeters sued the Mayo Clinic Arizona alleging wrongful death of the five lost preembryos, negligence, breach of fiduciary duty, and breach of a bailment contract. On motion for summary judgment, the trial court dismissed all four claims. But on appeal the latter three claims were reinstated, and only the wrongful death claim was dismissed. ${ }^{37}$

Dismissal of the wrongful death claim was essentially a two-part process for the court. The Jeter court first decided that Arizona law did not recognize the pre-embryos as persons pursuant to the wrongful death statute as interpreted in Summerfield because the pre-embryos were not "viable.",38 Second, the court undertook an evaluation of the status of pre-embryos to decide whether the definition of "person" under the statute should be expanded to include preembryos. $^{39}$ The court decided the statute should not be expanded by judicial action but indicated the Legislature might be able to take such action. ${ }^{40}$ Wheth-

35. The author is a colleague of the IVF laboratory technician for the Arizona Center for Fertility Studies, a recently retired Arizona State University biology professor, Dr. Robert McGaughey. Because the case is pending trial, and he is both a fact and expert witness for the Jeters, Dr. McGaughey respectfully declined to discuss the case with the author. However, the Jeters' attorney graciously made Dr. McGaughey's deposition available.

36. The Mayo Clinic contends it transferred all ten pre-embryos and five embryos must have been lost due to the Arizona Center for Fertility Studies' failure to follow Mayo Clinic's thawing protocol.

37. Jeter v. Mayo Clinic Arizona, 121 P.3d 1256, 1260 (Ariz. Ct. App. 2005).

38. Id. at 1261 .

39. Id. at 1262 .

40. Id. at 1259 ("[W]e affirm the superior court's dismissal of the wrongful death claim and hold that absent legislative action expanding the wrongful death statutes, as a matter of law, a cryopreserved, three-day old fertilized human egg is not a "person" for purposes of that statute."). 
er the second part of the analysis was actually necessary was a matter debated by the three-judge panel and caused a specially concurring opinion to be filed.

The Majority aptly applies the Summerfield model of analysis to conclude that "a fertilized human egg outside the womb is not a 'person' within the meaning of A.R.S. $\S 12-611$ regardless of whether that fertilized egg constitutes human life or potential human life." I agree with this reasoning and, for that reason alone, I concur with the Majority's resolution of the first issue on appeal. However, in my view, resolution of the issue ends after application of Summerfield. Consequently, I believe the Majority's discussion of the debate concerning when life begins is unnecessary, and I therefore do not join in this portion of the decision. ${ }^{41}$

\section{B. Pre-Embryos Were Not Viable}

The Jeter court explained that the Arizona wrongful death statute does not define "person.," ${ }^{, 2}$ In Summerfield, the Arizona Supreme Court stated the word "person" included a viable fetus. ${ }^{43}$ In 2000 , the Arizona Legislature superficially amended a portion of the wrongful death statute without comment, so it can be assumed the Legislature both knew and approved of the Summerfield definition of "person." "44 Therefore, the Jeters can only make a claim for wrongful death if their pre-embryos were "viable."

In their brief to the court, the Jeters called the pre-embryos "viable frozen embryos" as a statement of fact. ${ }^{45}$ In his deposition, Dr. Robert McGaughey of the Arizona Center for Fertility Studies described the pre-embryos as "viable" several times, by which he seemed to mean there was no discernable reason why the pre-embryos could not be used successfully to impregnate Mrs. Jeter. ${ }^{46}$ The Jeter court rejected this terminology, saying it was not a factual claim stating "While the Jeters' complaint refers to these fertilized eggs as 'viable embryos,' such a characterization is a conclusion that is not necessarily implied from the well-pleaded facts. ${ }^{, 47} \mathrm{~A}$ fair question would be whether viability can

41. Id. at 1276 (Timmer, J., specially concurring).

42. Id. at 1263 .

43. Summerfield v. Super. Ct., 698 P.2d 712, 722 (Ariz. 1985).

44. Jeter, 121 P.3d at 1263.

45. Jeter, 121 P.3d at 1259.

46. Dr. McGaughey's deposition was not taken until December 2006, long after the Court of Appeals ruling. The Jeter court was not presented with any expert testimony by any of the medical doctors or scientists involved on the issue of viability.

47. Jeter, 121 P.3d at 1259. Because the case was before the court on appeal from summary judgment, the court was required to accept the facts in a light most favorable to the Jeters. 
ever be proved by factual assertions. To answer this question one must first understand what viability means under the law.

The use of fetal viability in American law traces its lineage back to a dissent by Justice Carroll C. Boggs in the 1900 Illinois Supreme Court case of $\mathrm{Al}$ laire v. St. Luke's Hospital. ${ }^{48}$ Thomas Allaire, an infant, sued for injuries he suffered while his mother was riding an elevator in the defendant's hospital while on her way to the obstetrics ward for delivery. Because Thomas was still in the womb at the time of the alleged negligence, the court dismissed his claim, stating that the infant plaintiff did not have a distinct and independent existence but was a part of his mother and that the injury was to her, not the infant. In a dissent that became influential a half-century later, Justice Boggs wrote,

A foetus in the womb of the mother may well be regarded as but a part of the bowels of the mother during a portion of the period of gestation; but if, while in the womb, it reaches that prenatal age of viability when the destruction of the life of the mother does not necessarily end its existence also, and when, if separated prematurely, and by artificial means, from the mother, it would be so far a matured human being as that it would live and grow, mentally and physically, as other children generally, it is but to deny a palpable fact to argue there is but one life, and that the life of the mother. Medical science and skill and experience have demonstrated that at a period of gestation in advance of the period of parturition the foetus is capable of independent and separate life, and that, though within the body of the mother, it is not merely a part of her body, for her body may die in all of its parts and the child remain alive, and capable of maintaining life, when separated from the dead body of the mother. If at that period a child so advanced is injured in its limbs or members, and is born into the living world suffering from the effects of the injury, is it not sacrificeing truth to a mere theoretical abstraction to say the injury was not to the child, but wholly to the mother? ${ }^{49}$

In a later case in 1933, the Supreme Court of Canada allowed a claim for injuries suffered by a viable fetus, reasoning that because criminal law punished the particular conduct in question, civil law should likewise recognize the same

Had the case been on appeal from a trial verdict, the court would accept the findings of the trier of fact, usually a jury. The court remains free to apply the law as it sees fit to the facts presented.

48. Allaire v. St. Luke's Hospital, 56 N.E. 638 (Ill. 1900).

49. Id. at 641 (Boggs, J., dissenting). 
conduct as constituting a tort. ${ }^{50}$ But it was not until after World War II that an American court recognized a cause of action for injury or death to a viable fetus, which occurred in the District of Columbia decision of Bonbrest v. Kotz, in 1946.51

Here, however, we have a viable child - one capable of living outside the womb-and which has demonstrated its capacity to survive by surviving - are we to say now it has no locus standi in court or elsewhere?

As to a viable child being 'part' of its mother - this argument seems to me to be a contradiction in terms. True, it is in the womb, but it is capable now of extrauterine life - and while dependent for its continued development on sustenance derived from its peculiar relationship to its mother, it is not a 'part' of the mother in the sense of a constituent element-as that term is generally understood. Modern medicine is replete with cases of living children being taken from dead mothers. Indeed, apart from viability, a non-viable foetus is not a part of its mother. ${ }^{52}$

Judging from this language, the Bonbrest court may very well have extended the right to compensation even to non-viable fetuses, had the facts of the case warranted it. Still, the court continued to insist that the child be born alive before an action could be brought, even if the injury occurred while in the womb. From these early cases, it is clear that viability meant actual survival when something happened to endanger the health of the mother, and actual survival was evidence of a separate existence apart from the mother. The Bonbrest court seemed to point out that it was a separate existence that defined a person, but it was actual survival that gave evidence of that separate existence.

By the time of Roe v. Wade ${ }^{53}$ in 1973 , the concept of viability had progressed from actual survival into the potential to survive. The Roe Court did

50. Montreal Tramways v. Léveillé, [1933] S.C.R. 456 (Can.). The criminal law in question was the Infant Life Preservation Act, $19 \& 20$ Geo. V. (1929) (Eng.). See generally P.H. Winfield, The Unborn Child, U. TORONTO L.J. 278, 278 (1942).

51. Bonbrest v. Kotz, 65 F.Supp. 138 (D.D.C. 1946) (citing favorably the reasoning from Montreal Tramways v. Léveillé).

52. Bonbrest, 65 F. Supp. at 140, n.11 (citing GEORGE W. CORNER, OURSELVES UNBORN: AN EMBRYOLOGIST's ESSAY ON MAN, 1, 69 (Yale University Press) (1944) ("By the eighth week the embryo or foetus, as we now call it, is an unmistakable human being, even though it is still only three-quarters of an inch long....Indeed, the Chinese have long recognized that when a man is born he is already nine months old. Each of their babies is given at birth a full year's credit on the reckoning of its age."); (also citing ESTHER M. GREISHEIMER, PHYSIOLOGY AND ANATOMY 738 (J. B. Lippincott \& Co.,) (5th ed. 1945)).

53. Roe v. Wade, 410 U.S. 113 (1973). 
not initiate this change, but the magnitude of its decision validated the point. After Roe, whether or not the embryo or fetus actually survived became much less important.

Physicians and their scientific colleagues have... tended to focus either upon conception, upon live birth, or upon the interim point at which the fetus becomes 'viable,' that is, potentially able to live outside the mother's womb, albeit with artificial aid. Viability is usually placed at about seven months ( 28 weeks) but may occur earlier, even at 24 weeks. ${ }^{54} \ldots$.

[T] he State does have an important and legitimate interest in preserving and protecting the health of the pregnant woman... and... it has still another important and legitimate interest in protecting the potentiality of human life. These interests are separate and distinct. Each grows in substantiality as the woman approaches term and, at a point during pregnancy, each becomes 'compelling.'....

With respect to the State's important and legitimate interest in potential life, the 'compelling' point is at viability. This is so because the fetus then presumably has the capability of meaningful life outside the mother's womb. ${ }^{55}$

Furthermore, the Roe Court clearly ruled that the State had a legitimate interest in embryonic and fetal life from the earliest stages of development. ${ }^{56} \mathrm{Vi}$ ability only had significance insofar as it created a tipping point in favor of the state's interests over the pregnant woman's rights pursuant to the Court's constitutional substantive due process formulation. That is, the state's interest must be "compelling." 57 State courts, however, were slow to recognize the significance of the Roe decision in fields of law other than abortion. Some courts focused on the woman's right to an abortion and mistakenly granted those same rights to third parties. ${ }^{58}$ However, in the decades since 1973, a clear trend

54. Id. at 160 .

55. Id. at $160-63$.

56. Id. at 158 .

57. Id. at 163 .

58. See, e.g., Toth v. Goree, 237 N.W.2d 297 (Mich. Ct. App. 1975) (“Roe v. Wade .. . has had a considerable impact on the legal status of the fetus.... If the mother can intentionally terminate the pregnancy at three months, without regard to the rights of the fetus, it becomes increasingly difficult to justify holding a third person liable to the fetus for unknowingly and unintentionally, but negligently, causing the pregnancy to end at that same stage. There would 
emerged that expanded legal protections for embryos and fetuses to developmental stages earlier than viability.

The minority position among jurisdictions in 1973, soon became the majority position in large part because of Roe. The new majority position said it was not necessary for the infant to be born alive in order to recover damages, but only that an infant must be physically capable of surviving had it been born at the time of the injury. The move from the minority position to the majority position was an attempt by courts to eradicate a gap in the law whereby a wrongdoer who caused a fetus to die in the womb was punished less than one who merely caused injury to the fetus that could still be born alive. Within a decade after Roe, the majority position was that it was not necessary for a viable fetus to be born alive in order for a cause of action to exist for its death or injury. $^{59}$

Although this remains the current consensus, it seems an exceedingly odd legal fiction. ${ }^{60}$ In cases that arose under this viability legal fiction, no infant was born alive, so survivability was no longer relevant. It is just as accurate to claim that, but for an injury, a seven-week-old embryo would have been born alive, as it is to make the claim for a seven-month-old "viable" fetus. ${ }^{61}$ This logical conclusion is what led courts to reject viability as a standard for when a non-fatal injury was tortious - an infant that was injured prior to viability was just as damaged as one injured post viability. After Roe, viability became a legal fiction that represented two rationales. First, viability represented a way to biologically justify a social balancing act between fetal life and women's rights. Second, it was also a vestige of old ideas about fetal survivability that was rendered obsolete by abolition of the "born alive" rule that remained settled precedent. Increasingly, courts and legislatures are distinguishing the former rationale as only applicable to abortion and abandoning the latter. ${ }^{62}$

be an inherent conflict in giving the mother the right to terminate the pregnancy yet holding that an action may be brought on behalf of the same fetus under the wrongful death act.").

59. Summerfield v. Super. Ct., 698 P.2d 712, 722-3 (Ariz. 1985) ("At present, thirty-two jurisdictions recognize a cause of action for wrongful death when a viable fetus is stillborn as a result of tortious negligence. Only ten jurisdictions (including Arizona, per Kilmer v. Hicks, supra) do not recognize such a cause of action unless live birth takes place. Thus, the statement in Kilmer v. Hicks, supra, that only a minority of courts allow the action, no longer holds true.").

60. This is not a new characterization of the problem with viability as a demarcation. See, e.g., University of Pennsylvania, The Impact of Medical Knowledge on the Law Relating to Prenatal Injuries, 110 U. PA. L. REv. 554, 554 (1962). In the 1950s, viability was the dividing line in most jurisdictions for tort actions filed after live birth, that is, an infant could only sue for prenatal injuries if they happened after viability. That rule was criticized and eventually abolished in all U.S. jurisdictions.

61. Although proof may be more difficult.

62. See, e.g., Minnesota v. Merrill, 450 N.W.2d 318, 322 (Minn. 1990) ("The state's interest in protecting the "potentiality of human life" includes protection of the unborn child, whether an embryo or a nonviable or viable fetus. In this context, the viability of the fetus is "simply immaterial" to an equal protection challenge to the feticide statute."); Wiersma v. Maple Leaf Farms, 543 N.W.2d 787, 792 (S.D. 1996) ("[T] he concept of viability is outmoded in tort law. "Viability" as a developmental turning point was embraced in abortion cases to balance the privacy rights of a mother as against her unborn child. For any other purpose, viability is purely an arbitrary milestone from which to reckon a child's legal existence.”); Farley v. Sartin, 466 
But, the issue in Jeter was whether in vitro pre-embryos were viable. The court therefore argued that the Jeters' situation was different from embryos in the womb, even though the pre-embryos were apparently surviving independently of Mrs. Jeter's body, albeit in a cryopreserved condition, before they disappeared. Given the confused state of what viability means, it is perhaps not surprising the Jeter court searched for words to explain the situation.

It is important to understand what the Jeters argue. Neither in the superior court nor in this Court did the Jeters claim that they had evidence to support a view that a cryopreserved pre-embryo fits within the definition of a viable fetus as discussed in Summerfield, that is, an entity which can presently survive to birth outside of the womb. Rather, relying on various treatises, the Jeters contend that medical science has so advanced since the supreme court decided Summerfield, that as a matter of law and statutory construction, this Court should expand the definition of a 'person' articulated in Summerfield to allow wrongful death actions for the loss of cryopreserved three-day-old eight-celled pre-embryos because they have the potential to become viable. They contend those medical advances allow such pre-embryos to maintain extrauterine life via the cryopreservation process. ${ }^{63}$

In other words, the Jeters argued their pre-embryos were viable because they were already living outside the womb. Judge Kessler called this definition "potential viability" and rejected it in favor of "present viability" because the pre-embryos would still have to go into the womb to develop. ${ }^{64}$ It is this distinction that prompted the curious language "survive to birth outside the womb." This language is curious because something that is already outside the womb cannot be "born" in any common sense of the word. The language is tortured because the viability standard cannot easily be applied to this circumstance. This is evident as the Jeter court also used the concept of uncertain survivability to bolster its finding that the pre-embryos were not viable.

Unlike a viable fetus, many variables affect whether a fertilized egg outside the womb will eventually result in the birth of a child. This makes it speculative at best to

S.E.2d 522, 533 (W. Va. 1995) (“After reviewing a number of nonviable unborn child decisions in jurisdictions that permit a cause of action for a viable unborn child, we can find no legitimate or persuasive reason to infuse the distinction into West Virginia's statute. We do not believe that proper application of stare decisis prevents us from rejecting an unjustified and unpersuasive majority position.").

63. Jeter v. Mayo Clinic Arizona, 121 P.3d 1256, 1259 (Ariz. Ct. App. 2005).

64. Id. 
conclude that but for the injury to the fertilized egg a child would have been born and therefore entitled to bring suit for the injury. ${ }^{65} \ldots$.

For cryopreserved pre-embryos, only $65 \%$ survived thawing and only $20.3 \%$ led to live births. Moreover, in $2001,72 \%$ of all assisted reproductive technology transfers failed to lead to a birth. ${ }^{66}$....

The Ninth Circuit adopted the viability concept endorsed by our supreme court in Summerfield, recognizing that, with regard to wrongful death actions, numerous courts had used "viability as the dividing line for 'personhood" because it denotes the point at which the fetus, in essence, becomes a person, or a 'separate entity capable of maintaining an independent action in its own right." The court found this test was particularly appropriate given that "the uncertainty of whether a pregnancy will culminate in a live birth is greatest at the beginning of a pregnancy. Thus, [courts] refuse to allow recovery because of the uncertainty and unpredictability of actions based on speculation that the fetus would have otherwise survived to viability." This reasoning is even more compelling here because the pre-embryos were cryopreserved for possible future use and might never have been implanted in the womb, much less survive to a live birth. $^{67}$

If the likelihood of a child making it to birth is very low, such as the one in five chance given by the President's Council on Bioethics to frozen preembryos, then a sound argument can be made that the pre-embryo is not a person, if you assume that survivability to birth is an important criterion. However, the modern viability standard presumes that surviving to birth is not important, but that the potential to survive is. Each of the five pre-embryos had the potential to survive. ${ }^{68}$ And, in any case, the likelihood that one of the five

65. Id. at 1262 (citing Robertson v. Sixpence Inns of Am., Inc., 789 P.2d 1040, 1047 (Ariz. 1990)).

66. Id. at 1266 (citing The President's CounCIL ON BIOETHICS, U.S. Public Policy AND THE BiotechNologies THAT TOUCH THE BEgINNINGS OF HuMAN LIFE: A DETAILED OVERVIEW (2003), available at http://www.bioethics.gov/background/biotechnology.html (last visited Apr. $29,2008)$ ).

67. Id. at 1270 (citing Santana v. Zilog, Inc., 95 F.3d 780, 783-84 (9th Cir. 1996).

68. This potential to survive is what the author believes Dr. McGaughey was talking about when he described the in vitro pre-embryos as "viable" several times in his deposition. This is also the usage preferred by the Jeters in their factual argument to the court that was rejected. 
pre-embryos would survive to birth was much higher than twenty percent, so a counter argument could be made that a group of five pre-embryos likely contains at least one that will survive to birth and thus should be considered a person, under this criteria. ${ }^{69}$ The court's comment that the pre-embryos "might never have been implanted in the womb" seems irrelevant for the case it was deciding because the Jeters intended to have them implanted.

The Jeter court went on to define viability in concrete terms as though viability was a phase of biological development. "[V]iability means that, once implanted in the womb, the embryo has reached a stage of development that, if it is taken out of the womb, it would be viable." ${ }^{, 70}$ Even disregarding the circular definition, this statement misstates what viability actually means in this context. Applying Arizona's wrongful death law as interpreted in Summerfield and Jeter, viability means after implantation in the womb, the typical embryolfetus would have developed long enough that it probably would live for a reasonable period of time outside the womb under medical supervision, assuming we disregard the injury which caused death in this case. The Jeter court added the after implantation in the womb part to the Summerfield definition in order to find that in vitro embryos were not viable. Without that proviso, a solid argument could be made that in vitro embryos satisfy the criteria of viability. This is not to suggest that the Jeter court was wrong for doing so. The Arizona Legislature had just modified the manslaughter statute to exclude in vitro embryos from its purview.

It is fair to ask why the courts are still making modifications to the viability standard when it is such a poor method for evaluating legal protections for early-stage human life. The Jeter court accurately stated "The Jeters do not contend that three-day-old, eight-celled cryopreserved pre-embryos can exist and develop into viable entities ex- utero." 71 This language also is bizarre unless we assume a "viable entity" is some defined stage of development. One would think that an embryo capable of developing entirely ex-utero would be considered viable. Ethical and legal issues concerning the development of an artificial womb are now being seriously discussed. Two authors have suggested the creation of a legal fiction called "viability" equivalent to personhood (another legal fiction) that would occur at a defined stage of biological development when people can visually recognize the embryo or fetus gestating in an artificial womb to be human, which would presumably represent the point at which a human life begins. ${ }^{72}$ Such a stage of development has not yet been

69. Statistically, if there was an eighty percent chance each of the pre-embryos was a "dud" that would not survive to birth, then the chance all five were duds was about one in three. To phrase another way, there was a sixty-seven percent chance at least one of the pre-embryos would survive to birth after transfer to Mrs. Jeter's fallopian tube.

70. Jeter, 121 P.3d at 1265 (citing Thibert v. Milka, 646 N.E.2d 1025 (Mass. 1995).

71. Id. at 1265 .

72. Joyce M. Raskin \& Nadav Mazor, The Artificial Womb and Human Subject Research, in ECTOGENESIS: ARTIFICIAL WOMB TECHNOLOGY AND THE FUTURE OF HUMAN REPRODUCTION 159 (Scott Gelfand \& John R. Shook, eds., Rodopi BV 2006). 
defined, although many courts seem to believe there is one. An argument could be made that artificial wombs already exist in neonatal wards and are used to sustain the lives of premature infants. Such technology has uniformly been considered to extend the period of viability to earlier stages of pregnancy. As technology in neonatal care units improves, institutions move their "viability" estimates to earlier in gestation. ${ }^{73}$ Advances in technology affect the scientific proof of viability as well.

\section{Evidentiary Issues}

Whether or not a fetus was viable at the time of death or injury has generally been considered a question of fact for a jury to decide based on medical testimony. ${ }^{74}$ This principle was described by an Illinois court in 1978.

Relying principally on "Obstetrics" by Professor Nicholson J. Eastman, Professor of Obstetrics at Johns-Hopkins University, defendants argue that the smallest, youngest fetus ever to have survived was 20 weeks and weighed approximately 400 grams; that the fetus in this case at 14 weeks would probably weigh less than 120 grams and as a matter of law, was not viable. We note that the edition (10th) of "Obstetrics" upon which defendants rely was published in 1950, and we have not been favored with information concerning the opinions expressed in the four editions published since that time.

From our review of the authorities we are unable to say that as a matter of law the unborn infant was not viable at the time of the occurrence which allegedly caused its "death." It does not appear that in the present state of medical science it can be held that beyond question the fetus here involved could not have survived separate from and independent of its mother. Under the circumstances we hold that the question whether the unborn infant was viable at the time of the occurrence was one of fact and the appellate and circuit courts erred in deciding the question as one of law. ${ }^{75}$

73. See, e.g., New Scientist.com, World's Most Premature Baby Set to Leave Hospital, NEw SCIENTIST, Feb. 20, 2007, http://www.newscientist.com/article/dn11222-worlds-mostpremature-baby-set-to-leave-hospital.html (last visited Apr. 29, 2008).

74. Green v. Smith, 377 N.E.2d 37 (Ill. 1978); See also Fed. Credit Union v. Tucker, 853 So. 2d 104 (Miss. 2003) (indicating whether child was "quick" was a fact issue for the jury).

75. Green v. Smith, 377 N.E.2d 37, 39 (Ill. 1978). 
The Jeter court, however, ruled that the pre-embryos were not persons under the wrongful death statute as a matter of law because they were not viable. That is, no medical or scientific testimony would have swayed the court on this issue because the pre-embryos were not implanted in the womb. The court decided that implantation was a prerequisite for viability (which was required to be a person under the statute). In any case, neither party presented any evidence to the court regarding the viability of the pre-embryos. Both parties characterized in their briefs, the opinions and assertions made in a few extra-judicial learned treatises, mostly law journal articles. ${ }^{76}$ Additionally, the Jeter court itself undertook an extra-judicial investigation into the various legal, philosophical, biological, and religious ideas about the beginning of life. None of this material was subject to any evidentiary standards.

We summarize our understanding of the current state of knowledge of embryonic development not to dictate or prejudge any decision as to when life should be considered to begin for purposes of a wrongful death action. Rather, we do so to fairly respond to the Jeters' claim that, as a matter of law, a court should re-interpret the wrongful death statutes to define "person" to include a cryopreserved three-day old, eight-celled fertilized egg. The following summary is taken from a number of sources, including Maienschein at 256-62; Ronald M. Green, The Human Embryo Research Debates-Bioethics in the Vortex of Controversy at 6-8, 27-29, 42 (2001) ("Green"); Andrea L. Bonnicksen, Crafting a Cloning Policy-From Dolly to Stem Cells at 20-25 \& 69-71 (2002) ("Bonnicksen"); James A. Thomson, Human Embryonic Stem Cells, in The Human Embryonic Stem Cell Debate (Suzanne Holland, Karen LeBacqz, Laurie Zoloth, eds.) (2001) ("Holland") at 15; Thomas A. Shannon, From the Micro to the Macro, in Holland at 178 ; Kiessling at 1055-65.",77

The court's denial that it was prejudging any decision as to when life should be considered to begin is interesting because it repeatedly invited the Legislature to make such a decision. Nevertheless, the court's purpose in conducting this literature review was to express the reason for its refusal to expand

76. Jeter, 121 P.3d at 1267.

77. Id. at 1266 . It is worth noting the disciplinary expertise of each of the authors cited by the court in support of its statements about developmental biology: Maienschein (History and Philosophy of Biology); Green (Religion); Bonnicksen (Political Science); Thomson (Cell Biology); Shannon (Religion and Social Ethics); Kiessling (Biochemistry). 
the meaning of "person" beyond viability to include pre-embryos. That is, after concluding that the existing standard for personhood was viability, and that the pre-embryos did not meet that standard as a matter of law, the court addressed whether or not it should go ahead and change the standard to include preembryos as persons in the absence of viability. The reason the court refused to expand the definition of "person" was essentially that there was no consensus among authors of learned treatises on the answer to the question of when human life begins. ${ }^{78}$ But most authors agreed that a pre-embryo does not qualify as a human life.

While the Jeters rely on several medical-legal texts to support their argument that human life begins at conception, those texts are only part of the discussion among scientists, philosophers, ethicists and the public as a whole on the issue of when society should consider life to begin. Most of these authors do not support the idea of expanding the concept to cryopreserved pre-embryos. 79

Given this lack of support for the Jeters' position, the court decided to let stand the Summerfield decision that a fetus must be viable to be a person for wrongful death purposes, in spite of the fact that the viability standard was undeniably a minority position in the literature as well. When one considers all the literature promoting opinions about when a human life begins whether it be based upon biology, philosophy, religion, or any other thinking disciplines, one is still left to wonder how the viability standard manages to endure in the face of so much dissent. ${ }^{80}$ The lack of consensus naturally calls for an answer to the question, who gets to decide what the standard is? If the Arizona Legislature defined "person" as the "product of conception at any stage of development," as it was defined in the pre-2005 manslaughter statute, would the courts then accede to this definition despite the lack of support from learned authorities? From the court's many invitations to the Legislature, it seems it would.

As explained by both Forsythe at 504-10 and Green at 22-25 and 63-66, there are various theories of what constitutes a "person." One current analysis is to examine various subjective attributes including the capacity to feel pain, experience pleasure, survive and react to the environment. In contrast, various authors taking a deve-

78. Id. at 1268 .

79. Id. at 1267 .

80. Viability gains most, if not all of its persuasive force from abortion precedent. See Roe v. Wade, 410 U.S. 113 (1973).

81. ARIz. ReV. Stat. AnN. § 13-1103 (2007). 
lopmental perspective consider implantation, development of the embryonic disc at fourteen days of fertilization, sentience, viability and/or the existence of brain waves. The 1994 National Institutes of Health Human Embryo Research Panel took a pluralistic approach, examining the increasing possession of qualities that make respecting the entity more compelling. An opposing view contends a human being is created at the time of fertilization because at that time the embryo has an active capacity to eventually articulate itself into a human being. Forsythe at 474-78. The lack of any clear, generally accepted concept of when "personhood" occurs further supports leaving the decision as to further expanding the term "person" for wrongful death purposes to the Legislature. ${ }^{82}$

In its opinion, the court in Jeter stated twenty-one times that it should be for the Legislature, not the courts, to decide whether or not to change the definition of "person" in the wrongful death statute. Does this mean the courts would completely abdicate the authority to decide when human life begins, even so far as to allow the Legislature to count in vitro embryos as persons? We will soon have one answer to that question when the Illinois courts reach a final decision in the Miller case. ${ }^{83}$ Given the statutory scheme in Louisiana, a similar issue could arise there. ${ }^{84}$ The court in Jeter was clear in its belief that the Legislature is better situated to decide such issues.

Indeed, there are important societal interests which help fuel the current discussion concerning when life should be considered to begin. On the one side is the contention that there are benefits of utilizing human preembryonic material for stem cell research to diagnose and treat severe medical conditions, including infertility. This interest, however, is balanced against respect for human life...

It is the balancing of these two primary concerns that underscores the need for reasoned legislative, not judi-

82. Jeter, 121 P.3d at 1267-68.

83. Miller v. American Infertility Group, No. 02-L-7394 (Cir. Ct. Cook County, Ill. Feb. 4, 2005). See also LA. REv. STAT. ANN. § 9:123 (2006) (“An in vitro fertilized human ovum exists as a juridical person until such time as the in vitro fertilized ovum is implanted in the womb; or at any other time when rights attach to an unborn child in accordance with law."). 
cial, decision-making as to the nature of a "person" under the wrongful death statutes ... ${ }^{85}$

Leaving the decision to the Legislature is a solid democratic position. But, is this a question that should be answered through the political process, or is it a question that should be answered, at least in part by science? After all, we are not talking about, for example, whether children should be able to obtain Social Security survivor benefits if their father died while they were frozen embryos before they were implanted in the womb using IVF ${ }^{86}$ We are talking about whether the embryo is a human being whose life is worthy of being protected by law. Is this a question we as a society wish to leave to the vagaries of political decision-making, beholden as it is to compromise, economics, interestgroup pressure, and the basest forms of populism? Should the definition of "person" in the wrongful death statute be affected by the group that raises more money between the stem-cell lobby and the right-to-life lobby? Because the courts are bound by definitions promulgated in statutes that are sources of litigation, courts remain unwilling to take a stand on when human life begins. ${ }^{87}$

\section{Science and Law}

The Jeter court devoted three of its ninety-four paragraphs to a general overview of the developmental biology of the human embryo from fertilization to eight weeks gestation and did not discuss the biology of the fetus. ${ }^{88}$ Neither party submitted any expert scientific testimony to the trial court or the court of appeals regarding when a human life begins. In the parties' briefs, the only sources cited that could be considered scientific was one citation to support statements about the number of frozen embryos in the United States, ${ }^{89}$ and two definitions from a medical dictionary. ${ }^{90}$ The court also cited a couple scientific sources independently. ${ }^{91}$

85. Jeter, 121 P.3d 1268-9.

86. See Woodward v. Comm'r of Social Sec., 760 N.E.2d 257 (Mass. 2002); GillettNetting v. Barnhart, 371 F.3d 593 (9th Cir. 2004).

87. Only one case stands apart as an instance in which a court rejected a legislature's definition of life in favor of its own. In Evans v. People, 49 N.Y. 86 (N.Y. 1872), the highest New York state court rejected the Legislature's penalties for causing the death of an unborn child prior to "quickening" on the grounds that an unborn child did not become alive until it was "quick," so no death could possibly occur. However, the New York Legislature had enacted several statutes over the preceding years with contradictory provisions and gaping legal loopholes. The court was merely affirming the common law rule. See also Means, C., The Law of New York Concerning Abortion and the Status of the Foetus 1664-1968: A Case of Cessation of Constitutionality, 14 NYLF 411 (1968).

88. Jeter v. Mayo Clinic Arizona, 121 P.3d 1256, 1266-1268 (Ariz. Ct. App. 2005).

89. Jeter, 121 P.3d at 1256 (citing Brief for Petitioner Appellant at 20, Jeter v. Mayo Clinic Arizona, 121 P.3d 1256 (Ariz. Ct. App. 2005) (No. 1 CA-CV 04-0048) citing to David Hoffman et al., Cryopreserved Embryos in the United States and Their Availability for Research, 79 FERTILITY AND STERILITY 1063, 1063 (2003)).

90. Jeter, 121 P.3d 1256 (citing Brief for Appellee at 8, 17, Jeter v. Mayo Clinic Arizona, 
All parties and the court treated the question of when life begins as a question of law only marginally affected by "constitutional" or "legislative" facts. ${ }^{92}$ From a financial perspective, this makes some sense. The Jeters, in particular, were probably not well situated to pay for the expert witness fees necessary to produce a record of sufficient weight to the point where it might alter the court's opinion that personhood was a question of law and not of fact. However, the court could have undertaken a more in-depth factual analysis of embryonic development had it been interested in deciding when a human life begins. Understanding the relevant science is becoming a new requirement for proper adjudication, as illustrated by Justice Breyer in the context of assisted suicide.

Is that right to assisted suicide part of the liberty that the Constitution protects? Underlying the legal question was a medical question: To what extent can medical technology reduce or eliminate the risk of dying in severe pain? The medical question did not determine the answer to the legal question, but, I believe, that to do our legal job properly we needed to develop an informed, though necessarily approximate, understanding of the state of that relevant scientific art. ${ }^{93}$

While the Jeter court stated something similar in its opinion, ${ }^{94}$ the thrust of the decision was exactly opposite from the sentiment of Justice Breyer's suggestion. The Jeter court did not use the scientific evidence it reviewed to guide its decision about when life begins. The Jeter court altogether rejected the idea of using scientific evidence to guide its decision. ${ }^{95}$ The Jeter court specifically stated that the multiplicity of opinion among scholars and the public as to when a human life begins was a valid reason to avoid deciding the issue. $^{96}$ The U.S. Supreme Court made the same claim in the Roe case-that it was not deciding the issue of when a human life begins. ${ }^{97}$ Nevertheless, courts

121 P.3d 1256 (Ariz. Ct. App. 2005) (No. 1 CA-CV 04-0048) citing to THE AMERICAN HeRITAGe STEDMAN's MEdical DictionaRy (Editors of the American Heritage Dictionaries eds., 1995)).

91. Jeter, 121 P.3d at 1266.

92. For a discussion of constitutional facts, see David L. Faigman, A Unified Theory of Constitutional Facts, http://law.bepress.com/expresso/eps/1149/ (last visited Apr. 29, 2008).

93. Breyer, supra note 2, at 24-5.

94. Jeter, 121 P.3d at 1258 ("Analytically, it is not the name but the biological details of development that should help guide the discussion of when to consider that life begins.").

95. Jeter, 121 P.3d at 1268.

96. Id.

97. Roe v. Wade, 410 U.S. 113, 159 (1973) (stating "We need not resolve the difficult question of when life begins. When those trained in the respective disciplines of medicine, philosophy, and theology are unable to arrive at any consensus, the judiciary, at this point in the development of man's knowledge, is not in a position to speculate as to the answer."). 
have persisted in finding that personhood begins at viability, just as the Jeter court did.

Certainly, "person" and "human being" could be different, and often are. Nevertheless, human developmental biology is a relevant factor in deciding the personhood of the human embryo or fetus. In New Jersey, a case is currently pending where a jury might be asked to decide if medical malpractice has been committed by an abortion doctor's failure to inform his patient that her six-toseven week old embryo was a complete, unique, living human being. ${ }^{98}$ In order for a jury to make such a decision, the parties will have to submit extensive expert biological testimony. Juries only decide fact questions, so they will need to know all the facts about embryonic development. The same kind of circumstance could arise in a case involving cryogenically preserved pre-embryos. Would the court in such a case rule that whether the pre-embryo is a complete, unique, living human being is a question of fact for a jury to decide? This raises the prospect of contradictory resolution of identical fact patterns, as often can happen with jury decisions in multiple cases because they are independent of one another. Jury selection in such a case would be a harrowing experience. Because there seem to be so many conflicting opinions about life based on philosophy, religion, personal experiences, and plain old politics, it might be difficult for a jury to come to a decision. Of course, the same could be said of many issues that juries routinely decide.

If a jury must decide the fact question of whether an embryo is a complete, unique, living human being in a lack-of-informed-consent malpractice case, then why would a wrongful death case such as Jeter be different? The issue certainly seems to be the same. If the embryo is a living human being, then the Legislature's statutory intent to create a cause of action for compensation to survivors of a "person" wrongfully killed would be frustrated by a ruling that the embryo is not a person as a matter of law. The trier of fact, most likely a jury, would have to decide if the embryo is a person.

\section{CONCLUSION}

The Jeter decision presents some interesting questions about how our legal system decides issues of embryo and fetal personhood. The viability standard has been ensconced in the judicial system for many years and remains a strong precedent for deciding when a human life begins because of the Roe decision and the continuing abortion debate. However, the viability standard has lost almost all its support and intellectual force outside the context of abortion. Legislatures now routinely promulgate criminal and civil statutes that afford protection to the embryo at a very early stage of development. Courts have not interfered with these legislative standards, but courts have conservatively relied on the old viability standard in the absence of legislative action. 
The determination of when a human life begins has been viewed as both a question of law for the judge to decide and a question of fact for a jury to decide. The Jeter court viewed the question as one of law, and refused to expand the meaning of "person" in Arizona's wrongful death statute to include preembryos because there was not much support for such a view in the literature the court consulted. However, because the question was one of law, the court did not have expert testimony or extensive evidence about developmental biology. A jury, on the other hand, would have access to this evidence in resolving a question of fact. Cases may soon go to a jury to decide when a human life begins in New Jersey and South Dakota, if the courts in those states allow it to happen. The time appears to be fast approaching when the judiciary will have to stake out a uniform position about when human life begins. One would hope that decision will be made using the best available scientific evidence. 
